\title{
Brands make believe: ethical veganism and labelling in fashion
}

\author{
To wear the arctic fox \\ you have to kill it. Wear \\ qiviut-the underwool of the arctic ox- \\ pulled off it like a sweater; \\ your coat is warm; your conscience, better. \\ If you fear that you are \\ reading an advertisement, \\ you are. If we can't be cordial \\ to these creatures' fleece, \\ I think that we deserve to freeze.
} Marianne Moore, The Arctic Ox, 13 September 1958, New Yorker $^{1}$

In January this year, in Casamitjana Costa $v$ The League Against Cruel Sports, ${ }^{2}$ the Employment Tribunal held that ethical veganism is a philosophical belief under section 10 of the Equality Act $2010 .^{3}$ This preliminary ruling on veganism was part of an unfair dismissal case,${ }^{4}$ in which the claimant maintained that he was dismissed because of his ethical veganism. Although as a first instance decision it is merely persuasive on subsequent tribunals, the case has attracted wide publicity and any decision seeking to depart from it would likely be viewed as quite controversial without providing good reasons to distinguish itself. While some may say that the decision does not technically change the law, this is just half the story. ${ }^{5}$ Indeed, in many respects it changes everything.

1. Later published as The Arctic Ox (or Goat), in M Moore, O To Be A Dragon (Viking Press, New York 1959).

2. Casamitjana Costa v The League Against Cruel Sports (21 January 2020), Case Number: $3331129 / 2018$.

3. Section 10(2) provides: 'Belief means any religious or philosophical belief and a reference to belief includes a reference to a lack of belief'.

4. The unfair dismissal case subsequently settled in March 2020. It is notable that discrimination claims are apparently common in dismissals within the first two years of employment, because during this period an employee may be dismissed without a fair reason (therefore, unfair dismissal will not apply) pursuant to section 108 (qualifying period of employment) which provides that the right (not to be unfairly dismissed) under section 94 does not apply to the dismissal of an employee unless that employee has been continuously employed for a period of not less than two years ending with the effective date of termination. These were the circumstances in Gray v Mulberry discussed later.

5. Yara Ali-Adib, who specializes in discrimination and human rights law, describes the decision as 'simply a reflection of a progressive society'. See Y Ali-Adib, 'The Ethical Veganism Case: A Reflection of a Progressive Society', Legal Cheek, 8 January 2020. See further, J Slingo (2020) 'Veganism Judgment Doesn't Change Employment Law, Expert Notes', The Law Society Gazette, 3 January <https://www.lawgazette.co.uk/news/veganism-judgmentdoesnt-change-employment-law-expert-notes/5102613.article>. 
It is a question of fact whether a particular person's veganism is ethical, but ethical veganism is a philosophical belief and thus is a protected characteristic under UK discrimination law, and this has important consequences for producers.

The decision was reported in the press as a 'landmark legal case', ${ }^{6}$ a 'landmark ruling, 7 and as making history. ${ }^{8}$ However, some of the press continued to report on veganism as a diet or lifestyle choice, with one headline even claiming, 'Court rules lifestyle choice is same as philosophical belief'. ${ }^{9}$ This equation of veganism with diet is not uncommon, and it continues to preoccupy perspectives on the meaning and practice of veganism. Indeed, even in the excellent recent collection, Ethical Vegetarianism and Veganism, ${ }^{10}$ the chapters all deal with veganism primarily in the context of diet, with no detailed attention to veganism in fashion, although the editors do note clothing in the UK Vegan Society's definition of veganism. ${ }^{11}$ Further, while there are several registered trade marks in relation to vegan products, these are almost always concerned with food and similar high-moving household consumer goods, rather than fashion and other areas. ${ }^{12}$ But as the decision states:

Ethical veganism is not just about choices of diet, but about choices relating to what a person wears, what personal care products he or she uses, their hobbies and the jobs he or she does. They are in fact people who have chosen to live, as far as possible, without the use of animal products. ${ }^{13}$

Again, the supermarket is just half the story. Now to the other half.

While much of the press has been concerned with the potential impact on employers, there has been more limited reference to the significance for other areas of life. ${ }^{14}$ What about consumers? As the decision itself explains, the claimant's belief necessitates taking 'all reasonable steps to ascertain whether a product or service that he consumes complies with ethical veganism', ${ }^{15}$ including clothing: 'The Claimant does not wear any clothes, shoes, hats or fashion accessories that contain animal products, which includes products containing wool, silk, fur, leather, teeth, horns or tortoiseshell., 16 Dietary veganism is arguably provided for through certification labelling in food, but the wider consumer protection issues in fashion products are a different story.

6. BBC News, 'Ethical Veganism is Philosophical Belief, Tribunal Rules', 3 January 2020 <https://www.bbc.co.uk/news/uk-50981359>.

7. BBC News, 'Jordi Casamitjana Vegan Tribunal a "Victory for Animal Protection", 2 March $2020<$ https://www.bbc.co.uk/news/uk-england-london-51709141>.

8. J Doward, 'Worker Could Make History in a Crucial Case for Ethical Vegans', The Guardian, 29 December 2019 <https://www.theguardian.com/lifeandstyle/2019/dec/29/ethicalvegan-jordi-casamitjana-protected-status-court-tribunal>.

9. K Ng, Veganism: Court Rules Lifestyle Choice is Same as Philosophical Belief, Independent, 3 January $2020<\mathrm{https}$ ://www.independent.co.uk/news/uk/home-news/vegantribunal-jordi-casamitjana-ruling-ethical-philosophical-belief-a9268856.html>.

10. A Linzey and C Linzey (eds), Ethical Vegetarianism and Veganism (Routledge, London 2019).

11. A Linzey and C Linzey, 'Introduction', in A Linzey and C Linzey (eds), Ethical Vegetarianism and Veganism (Routledge, London 2019) 2. The Vegan Society is discussed further below.

12. For a useful list of vegan marks, see $<$ http://vegan-labels.info $>$.

13. Casamitjana (n 2) para 16.

14. An exception is the brief but pertinent comment from BBC legal correspondent, Clive Coleman, in 'Analysis: Far-Reaching Effects', in BBC News, 'Ethical Veganism is Philosophical Belief, Tribunal Rules', 3 January $2020<$ https://www.bbc.co.uk/news/uk-50981359>.

15. Casamitjana (n 2) para 17.

16. Casamitjana (n 2) para 20.11. 
Indeed, the marketplace for a kind of 'regulatory' veganism branding is becoming quite vibrant. ${ }^{17}$ But how might it be possible to enforce a particular standard without specific legislation for veganism (for example, as exists for organic) ${ }^{18}$ and without transparent certification processes? ${ }^{19}$

Soon after the decision in Casamitjana, although there is no indication that it was a reaction to the judgment, the British Retail Consortium (BRC) published its Voluntary Guideline on Veganism in Fashion in an effort to clarify the definition of vegan clothing and related products in order to increase consumer confidence in ethical purchases: 'Consumers wishing to purchase vegan products are looking for assurances from retailers in the form of certification, labelling, or registration. ${ }^{, 20}$ Included in the Voluntary Guideline are templates for the bill of materials and for a vegan product declaration to be used with manufacturers and suppliers. Significant for the implementation and 'enforcement' of such voluntary guidelines are the social norms and the soft law of consumer action.

In addition to this recent action from the BRC, there are several vegan trade marks that are licensed to products through various different processes of qualification and individual contractual arrangements. ${ }^{21}$ The V-Label is a European trade mark, ${ }^{22}$ initiated by the European Vegetarian Union $^{23}$ and owned and administered by V-Label GmbH $(\mathrm{CH}){ }^{24}$ The V-Label is registered in several classes including class 25 (clothing, headgear, footwear) and is licensed through individual agreements undertaken with more than 1300 partners through which it is applied to more than 15000 products. ${ }^{25}$ Depending on the particulars of the product, the V-label is accompanied by the further qualifier of 'vegetarian' or 'vegan'. ${ }^{26}$ However, although

17. Also relevant in the fashion sector is the UK-based Vegetarian Society, which holds the registered trade marks Vegetarian Society Approved (UK TM - UK3200757) and Vegetarian Society Vegan Approved (UK TM - UK3200767) - both of which are registered in a range of classes, including class 25. The Vegetarian Society's fashion partnerships are limited, but they license extensive product ranges from Vendula (bags and accessories) as well as Nuevue (phone cases and accessories). Rather than self-declaration they approve products based upon an inspection process. See further <https://www.vegsoc.org/vegetarian-and-vegan-trademarks/>.

18. Council Regulation (EC) No 834/2007 of 28 June 2007 on organic production and labelling of organic products and repealing Regulation (EEC) No 2092/91. This Regulation will be replaced on 1 January 2021 by Regulation (EU) 2018/848 of the European Parliament and of the Council of 30 May 2018 on organic production and labelling of organic products, repealing Council Regulation (EC) No 834/2007.

19. In relation to animal welfare more generally, the only EU-wide system of compulsory labelling is for eggs in relation to production methods - Council Directive 1999/74/EC of 19 July 1999, laying down minimum standards for the protection of laying hens.

20. BRC, Voluntary Guideline on Veganism in Fashion (2020), <http://brc.org.uk/news/2020/ brc-veganism-in-fashion-voluntary-guideline/>.

21. For a useful list of vegan marks, see $<\mathrm{http}: / /$ vegan-labels.info $>$. See also the US registered Certified Vegan mark (US TM 85594160) <https://vegan.org/certification/>.

22. First registered in 2003 before the EU certification mark system came into effect.

23. The European Vegetarian Union (UVU) is an umbrella organization of European vegetarian and vegan bodies <https://www.euroveg.eu>.

24. See further $<$ https://www.v-label.eu $>$.

25. V-Label Brochure, Five Steps to V-Label, available at <https://www.v-label.eu/wp-content/ uploads/2019/01/v-label-flyer-dinlang-en-korr-0905.pdf>.

26. The criteria for the V-Label and the further specification of vegan or vegetarian are set out in the manual for licensees, available at <https://www.v-label.eu/wp-content/uploads/2019/11/vlabel-manual-for-licensees.pdf>. Examples of the mark are available at $<\mathrm{https://www.v-label.eu/}$ en/press/press-downloads>. 
registered in class 25 , the mark appears to be applied primarily to food products with some use also in cosmetics. ${ }^{27}$

The UK-based Vegan Society ${ }^{28}$ was established in the UK in 1944 and provides a definition of veganism that is quite widely cited - indeed, it is referred to in Casamitjana and also, as already mentioned, in the editors' introduction to Ethical Vegetarianism and Veganism. The normative authority of The Vegan Society also translates into a kind of regulatory environment for veganism in fashion.

The Vegan Society is the owner of the registered trade mark, The Vegan Society, protected in the UK and in jurisdictions around the world. ${ }^{29}$ However, the mark is registered only in respect of classes 16 (printed matter, etc.) and 41 (education and training, etc.). Nevertheless, The Vegan Society licenses its trade mark to businesses to use on over 32000 products worldwide, ${ }^{30}$ 'as the authentic standard for products free from animal ingredients and animal testing'. ${ }^{31}$ Partner brands are promoted very clearly and a search of The Vegan Society's current partners shows a collaboration with a range of fashion products, from apparel through to accessories and footwear, including familiar brands like Accessorize, Disney, New Look, and V.Gan. ${ }^{32}$

For all intents and purposes, this is a collaboration between brands, a co-branding between the product brand and The Vegan Society. ${ }^{33}$ As the oldest vegan 'brand', the society is in itself a trusted partner for this kind of collaboration. More than that, in so far as The Vegan Society is referenced as a group identity for ethical veganism, the trade mark functions as an identity for the consumer. That is, the essential function of The Vegan Society mark, in this relationship, is arguably not to identify The Vegan Society as the source of the product, but rather, the shared belief as a source of the product. The consumer recognizes not only the product, but also, and more significantly, the belief. In this way, absent any formal framework for vegan products, the regulatory framework for veganism is consumer-led.

27. While there is no public search function of products, the V-Label social media suggests the full range as cheese, fast food, ice-creams, sweets, milks, drinks, and cosmetics. See further $<\mathrm{https}$ ://www.instagram.com/vlabel.official/?hl=en>. Notably, there was a VLabel London clothing brand, sold through ASOS and other online fashion retailers. However, other than its retailers, its only online presence appears to be limited to a Facebook page (for which there is no activity after 2016) <https://www.facebook.com/vlabellondon/>. No connection to the V-Label was found, nor any connection to vegan clothing branding more widely, and the unregistered mark appears to be no longer in use.

28. <https://www.vegansociety.com>.

29. UK3027871; WE1234975.

30. <https://www.vegansociety.com/resources/lifestyle/shopping/trademark-search>.

31. <https://www.vegansociety.com/your-business/about-vegan-trademark>.

32. A fuller list of fashion and apparel partners includes Accessorize, Animal Aid, Apoio Produtivo, Avenue, Bearpaw, Blowfish Malibu, Cartago, Central Park Shoes, Colorme, Eurthlin, Copacabana, Disney, First Cost, Fjordson, Forever New Vegan, Freerangers, Gola Classics, Grendha, Grenson, Harper's Candles, Holster Global, Ipanema, Kula Bags, Ladybug, Maisa, Mel Infantil, Melissa and Mini Melissa, Mormaii, New Look, Piñatex, Rider, Risorse Future SRLS, RPU Comfort, Turma, V.Gan, Veganline, Wills Vegan Shoes, Zaxy and Zaxynina. A full product list may be searched at $<$ https://www.vegansociety.com/search/products/a $>$.

33. Indeed, the application process involves a pre-register questionnaire after which an individual quote is provided that takes into account the size and turnover of a company, rather than a basic certification fee. The process is then based upon self-declaration, whereby the relevant products are submitted with ingredient lists and evidence along with a fee, of which 50 per cent is refunded if an application fails. See further the information pack, 'Registering for The Vegan Society's Vegan Trademark', available on request from <https://www.vegansociety.com>. 
Thus, the humble trade mark also contributes to communicating, as it were, veganism as a philosophical belief. Indeed, in the language of the four functions of a trade mark, ${ }^{34}$ the communication of veganism as a philosophical belief is a critical part of the translation of this co-branding across a range of products and even different sectors of consumer goods. The Vegan Society mark can thus come to designate an enormous range of objects or products in so far as those products are simply cues to that belief, the real identity that is at stake for the consumer. In other words, veganism propels to the foreground the relationship between consumer identity and branding, the product being merely a vehicle for the relationship between those two brands (consumer and producer) through the origin story, if you like, of The Vegan Society mark.

In many respects, The Vegan Society mark provides a critical insight into branding and experience commodities. From the Casamitjana decision itself, ethical veganism is understood as taking 'all reasonable steps to ascertain whether a product or service that [the Claimant] consumes complies with ethical veganism' ${ }^{35}$ The fundamental relationship to the product is through the philosophical belief in which that product, so to speak, partakes. That is, the product is merely an artefact of the belief and the trade mark communicates the shared belief: 'The relationship between humans and other fellow creatures is plainly a substantial aspect of human life. ${ }^{36}$ This 'advertising' or promotion of belief is not inconsistent with other responses to the legal action itself. One journalist offered the curious and critical reaction that, 'resorting to the law to enforce one's rights is hardly the best way to promote support for one's views', and that insisting on one's rights is somehow 'foisting' those views on others. ${ }^{37}$ The same article goes on to declare that 'Using the law to enforce vegans' rights is like using a sledgehammer to crack a nut - a kind of needless passive aggression. ${ }^{38}$ It would seem that some journalists are apparently more anxious about reading an advertisement than others.

What this and similar objections perhaps overlook, is that the trade mark (and in some respects, also the litigation) is a kind of pro-social tool, making it possible for those sharing the same belief to identify the resources with which to participate in that community. This is a kind of brand community, but one which is beyond the product brand, as it were. It is a brand community cohered by the belief brand. And this constitutes the very pro-social capabilities of contemporary sustainability and welfare branding in the fashion industry. Where a brand is misleading in advertising and promoting its vegan credentials (or other relevant information) it may therefore be compromising that shared belief and therefore be anti-social, rather than pro-social, in this context. Other consumers who share that group belief may then intervene through their own actions: 'it turns out that others' moral views and behaviors exert a strong influence on social judgment'. ${ }^{39}$

There is an element of the idea of 'cancel culture' or 'call out culture' here, but there is arguably more than that in play. Research on shared reality in human development, particularly in the early stages of that development, provides some insight here, specifically because this is a conflict between brand identity and moral or

34. At least as identified by the Court of Justice: C-487/07 L'Oréal v Bellure [2009] ECR I-5185, para 58 .

35. Casamitjana (n 2) para 17.

36. Casamitjana (n 2) para 35.

37. J Dalton, 'Vegans Have Won this Court Case - But They're Losing Hearts and Minds', Independent, 6 January 2010, <https://www.independent.co.uk/voices/vegan-ethical-tribunaljordi-casamitjana-philosophical-belief-a9271886.html>.

38. Ibid.

39. L Heiphetz, 'The Development and Importance of Shared Reality in the Domains of Opinion, Morality, and Religion' (2018) 23 Current Opinion in Psychology 1-5, 1. 
philosophical belief: 'Infants and toddlers readily help others, share with others, and interfere when they see one person transgressing against another. ${ }^{40}$ The fact that, under the Equality Act 2010, there is no appreciable distinction between religion and belief is significant in the wider research context. ${ }^{41}$ In particular, with respect to religion:

these studies highlight the importance of shared religious beliefs for social evaluation. Indeed, religious views appear more powerful than some other forms of shared reality in shaping social judgments ... religious views may play a large role in social perception because religion, unlike many other mental states, is often construed as an identity that influences many aspects of life. ${ }^{42}$

This is consistent with the requirement for cogency, seriousness, cohesion and importance in a philosophical belief as applied in Casamitjana: 'There clearly does exist a community within businesses and restaurants which adheres to this ethical principal. The belief concerns the relationship between individuals and other living things in diet, clothing, consumption, travel and relationships and indeed many other aspects of daily life/living., 43

Thus, when it comes to shared philosophical belief, the impact on consumer behaviour is especially significant. Like religious and other philosophical beliefs, ethical veganism potentially 'constitutes a social identity'. ${ }^{44}$ It is this social identity with which the ethical trade mark communicates and from which, at the very same time, it emerges. In other words, there is a belief shared between the consumer and the brand. The consumer and the brand inhabit the same belief community.

But how does sustainability cooperate with the seemingly contrary principles of trends, cycles, and indeed fashion itself? How does a fashion brand survive by selling fewer units? Jean Baudrillard proclaimed 'We are at the end of production. In the West, this form coincides with the proclamation of the commodity law of value, that is to say, with the reign of political economy. First, nothing is produced, strictly speaking: everything is deduced. ${ }^{45}$ The notion of pro-sociality in contemporary branding is arguably important here. The trade mark itself becomes less about the circulation of units and more about the organization of belief. In other words, nothing is produced. The brand constitutes a social identity and belief; everything is deduced. Ethical branding is a sign of the times - literally.

This is in evidence in Stella McCartney's production of faux fur, which, in addition to the Stella McCartney trade mark, is marketed under a second registered trade mark, Fur Free Fur. ${ }^{46}$ The Fur Free Fur mark is a compelling example of the mark as belief. And when used in conjunction with the Stella McCartney brand, it not only motivates an identification of the product credentials, but also consolidates the ethical identity and profile of the Stella McCartney brand more widely. In this way, participation in

40. Ibid 1.

41. See further the discussion of ethical veganism as religion in the US context in L Johnson,

'The Religion of Ethical Veganism' (2015) 5(1) Journal of Animal Ethics 31.

42. Heiphetz (n 39) 3.

43. Casamitjana (n 2) para 37; the Employment Tribunal was applying the test from Grainger $v$ Nicholson [2010] ICR 360.

44. Heiphetz (n 39) 3.

45. J Baudrillard, Symbolic Exchange and Death, IH Grant (trans), M Gane (intro) (Sage, London 1976 [1993]) 9, original emphasis.

46. US TM 5816415 (word mark), EUIPO 013627311 (figurative) and WO 1260713 (figurative). 
the Stella McCartney and Fur Free Fur brands is not merely a participation in a brand community; rather, in a very real sense, it appeals to a community of shared belief. The product is in service of that belief. And the enforcement of a standard in respect of ethical veganism is through the brand and adherence to a philosophical belief. Transgression of that belief therefore compels consumer intervention in a normative commercial framework.

This points to the very significant social function of trade marks in an ethical consumer environment. This is much more than an aspect of experience branding. The product is merely a vehicle for the brand, a tool for the practice of a belief, the manifestation of that belief. The brand is the belief. The need for regulation is therefore perhaps less urgent in terms of introducing further labelling and certification, and perhaps much more relevant with respect to addressing misleading advertising. ${ }^{47}$ Consumer welfare is a branding issue. The nature of the brand as belief is important in this context. Misleading advertising changes nothing about a consumer's belief. In other words, even if misled, this advertising does not cause an ethical vegan to compromise their belief. As explained in Casamitjana, 'If the Claimant is unable to ascertain the animal involvement in an essential product or service, or if he has been misled regarding such involvement ... then the Claimant would not consider that he has transgressed his morals. ${ }^{48}$ On the contrary, and partly for that very reason, misleading advertising may amount to a form of discrimination against a belief. Labelling may lead to the purchase or even use of an inappropriate product, but the product is merely an artefact of that belief, which remains intact. In other words, the real relationship of discrimination is with the brand and the adherence to the belief. The potential consequences of Casamitjana for labelling appear to me to be somewhat underestimated (or even ignored) in the mainstream press.

The nature of the 'advertising' of belief is implied in the question of manifestation of one's philosophical belief. The requirement of manifestation was addressed in another recent discrimination decision, and one that ignited the interest of the intellectual property community; namely, the employment dispute between Anna Gray and the fashion label, Mulberry. Can a belief in copyright amount to a philosophical belief? An important aspect of the protection of a philosophical belief is the right to manifestation; that is, the right to express one's belief and to be protected against interference with that expression. In the judgment of the Employment Tribunal, the judge focused on manifestation of the purported belief, but appeared to do so also as part of the consideration as to whether the Claimant's belief in copyright met the criteria of a philosophical belief: 'Whilst the Claimant may have held those views privately, there was nothing in what she did or said to the Respondent which made them aware that she held them. ${ }^{49}$ The question of manifestation, and whether there was any evidence of the employer's interference in the manifestation of the belief, remained central before the Employment Appeal Tribunal (EAT). ${ }^{50}$

47. See the Truth in Advertising report on Morphe beauty products and the description of some products as vegan despite containing animal by-products: 'Morphe Jaclyn Hill Eyeshadow Palette', Truth in Advertising, 11 March 2020 <https://www.truthinadvertising.org/morphejaclyn-hill-eyeshadow-palette/>. See further the discussion in TFL, 'As Demand for Vegan Beauty Products Grows, the Risk of False Advertising Looms', The Fashion Law, 12 March 2020, <https://www.thefashionlaw.com/as-demand-for-vegan-beauty-products-grows-the-riskof-false-advertising-looms/>.

48. Casamitjana (n 2) para 17.

49. Gray v Mulberry (unreported), para 4.10 (extracted [2019] EWCA Civ 1720, para 18).

50. Gray v Mulberry Co (Design) Ltd [2019] ICR 175 (EAT), para 33: 'The question therefore is whether doing an act, or, as in this case, not doing a particular act (i.e. not signing the 
While the Claimant did not succeed in establishing her belief in copyright as a philosophical belief, the Employment judge speculated that copyright activism, on the other hand, may constitute a philosophical belief, largely because of the campaigning (and 'advertising' behaviour, as it were) for increased awareness of copyright infringement. ${ }^{51}$ It is not clear if manifestation is relevant to the existence of a belief, and the difficulty of separating the two is recognized; ${ }^{52}$ rather, it is a consideration with respect to whether exercise of that belief has been limited. Is an employee's belief in copyright without manifest behaviour in which the employer could interfere a philosophical belief? Can there be indirect discrimination if the belief is not made manifest? Both the Employment Tribunal judge and the EAT looked to the manifestation of that belief in copyright; belief as brand.

The decision was appealed again to the Court of Appeal, coincidentally also the first decision including Arnold LJ in his new role, which saw the Court decline to consider the issue of philosophical belief as it was not relevant: "whether or not [the belief] amounts to a philosophical belief within the terms of $\mathrm{s} 10$ is irrelevant, because it did not put the Claimant at a disadvantage' ${ }^{53}$ The reason the Claimant was dismissed had nothing to do with her belief, whether it existed or not, and so the question of whether a belief in copyright is a philosophical belief within the meaning of section 10 falls away: 'There was no causal link between that belief and either the Claimant's refusal to sign the Copyright Agreement (original or amended) or the Respondent's decision to dismiss her.' 54

Although the Court of Appeal did not consider substantively the issue of philosophical belief, what is significant about the judgment for the present discussion is its silence on this manifestation approach: 'Our judgment is not to be taken as endorsing this approach. ${ }^{55}$ Nevertheless, in the wider philosophical, social, and behavioural environments of shared beliefs, perhaps it is part of the sociality of philosophical beliefs that there is almost always a kind of social expectation of manifestation. In a social economy of attention, the notion of a private belief has become socially suspect. On the other hand, a vegan mark is a tool to ensure that an individual is able to manifest their belief. Trusting the trade mark makes it easier and freer to pursue a belief. The purchasing decision is thus a way of manifesting the belief, through the trade mark, that is perhaps as yet beyond the copyright narrative. Therefore, the proper protection of the trade mark might be said to become part of the manifestation of one's belief. Trade mark protection thus becomes an aspect of the proper protection against discrimination. While we might agree or disagree on copyright, in many respects it is more difficult to make believe.

Legacy or provenance in the brand is thus not limited to the suggestion of historicity and resilience. Rather, it has become instrumental in ethical consumption, and

Agreement), amounts to a direct expression of the belief concerned and whether it is "intimately linked" to it. If the act or omission does not satisfy those requirements then it does not fall to be protected.'

51. Gray v Mulberry (unreported), para 5.7.4 (extracted [2019] EWCA Civ 1720, para 19). Of course, this does not need to go as far as campaigning to be a protected belief: see Gray $v$ Mulberry Co (Design) Ltd [2019] ICR 175 (EAT), paras 42-3.

52. See the discussion in K Monaghan (2013) Monaghan on Equality Law (2nd edn, OUP, Oxford 2013) 5.276.

53. Gray v Mulberry [2019] EWCA Civ 1720, para 29.

54. Ibid para 29.

55. Ibid para 30. 
consumption is central to the transformation of the fashion industry. ${ }^{56}$ In what do consumers believe? Innovation in materials, in fashion cycles, in welfare and sustainability will be consumer-led ${ }^{57}$ and the revolution is, ultimately, a branded one. ${ }^{58}$

If you fear that you are reading an advertisement, you always already are. The mark is a sign of the times. Literally.

Johanna Gibson

March 2020

56. For example, see the discussion of traceable leather footwear from Josefin Liljeqvist and the link to animal welfare and sustainability in consumption of leather products in L Sherriff, 'Can Traceable Footwear Change the Fashion Industry's Attitude Towards Leather?', Forbes, 10 March $2010<$ <ttps://www.forbes.com/sites/lucysherriff/2020/03/10/can-traceable-footwearchange-the-fashion-industrys-attitude-towards-leather/\#24620b10fae6>. See further, the brand itself, Josefin Liljeqvist <https://josefinliljeqvist.com>.

57. For example, in relation to vegan cosmetics, see E Hammett, 'Vegan Beauty: How Conscious Consumers Are Driving Innovation in Ethical Cosmetics', MarketingWeek, 29 May $2019<$ https://www.marketingweek.com/how-conscious-consumers-are-driving-veganbeauty/>.

58. Josefin Liljeqvist notes this specifically in relation to traceable leather footwear and the brand's influence on transforming manufacturing more widely: 'our plan is to become an internationally strong and influential brand. We aspire to grow from shoes over to a full conceptual fashion house with a non-profit organization that helps animals in need, and presents a new price model for farming.' Quoted in Sherriff (n 56). 